\title{
Pengaruh Status Sosial Ekonomi Orang Tua Dan Motivasi Belajar Terhadap Prestasi Belajar Kimia Siswa SMA Negeri Di Kabupaten Konawe
}

\author{
Rasniaty ${ }^{1)}$, Dahlan ${ }^{2)}$, La Ode Ahmad ${ }^{2)}$ \\ ${ }^{1}$ Mahasiswa Pascasarjana Pendidikan Kimia Universitas Halu Oleo, \\ ${ }^{2}$ Dosen Pascasarjana Pendidikan Kimia Universitas Halu Oleo, \\ Email: iqraradhe@gmail.com
}

\begin{abstract}
This research aims to examine and analyze: (1) the influence of parents' socio-economic status on chemistry learning achievement, (2) the effect of learning motivation on chemistry learning achievement, (3) differences in motivation for learning coastal students with students in Watershed, (4) differences in learning achievement of coastal students with students in Watersheds. The location of this research is the SMAN in Konawe District. This type of research is associative research and data collection tools use questionnaires and student learning outcomes report cards. The population is 385 students. Sampling was done by proportional random sampling technique, with a sample of 193 people. Data analysis techniques used descriptive analysis and multiple regression. The results showed: (1) parents' socio-economic status towards chemistry learning achievement by 18\%; (2) learning motivation towards chemistry learning achievement by 29\%; (3) there are differences in motivation to learn coastal students with students in Watersheds, (4) there are differences in learning achievement of coastal students with students in Watersheds. Based on the results of this study, it was concluded that parents' socio-economic status and motivation had an influence on the high school chemistry learning achievement in Konawe District.
\end{abstract}

\section{Keywords: Parents' socio-economic; Motivation; and Learning achievement}

Abstrak: Penelitian ini bertujuan untuk menguji dan menganalisis: (1) pengaruh status sosial ekonomi orang tua terhadap prestasi belajar kimia, (2) pengaruh motivasi belajar terhadap prestasi belajar kimia, (3) perbedaan motivasi belajar siswa pesisir dengan siswa di DAS, (4) perbedaan dalam prestasi belajar siswa pesisir dengan siswa di DAS. Lokasi penelitian ini adalah SMAN di Kabupaten Konawe. Jenis penelitian ini adalah penelitian asosiatif dan alat pengumpulan data menggunakan angket dan kartu laporan hasil belajar siswa. Populasi adalah 385 siswa. Pengambilan sampel dilakukan dengan teknik proporsional random sampling, dengan jumlah sampel 193 orang. Teknik analisis data menggunakan analisis deskriptif dan regresi berganda. Hasil penelitian menunjukkan: (1) status sosial ekonomi orang tua terhadap prestasi belajar kimia sebesar 18\%; (2) motivasi belajar terhadap prestasi belajar kimia sebesar 29\%; (3) ada perbedaan motivasi belajar siswa pesisir dengan siswa di DAS, (4) ada perbedaan prestasi belajar siswa pesisir dengan siswa di DAS. Berdasarkan hasil penelitian ini, disimpulkan bahwa status sosial ekonomi orang tua dan motivasi memiliki pengaruh terhadap prestasi belajar kimia SMA di Kabupaten Konawe.

Kata kunci: Sosial ekonomi orang tua; Motivasi; dan Prestasi belajar

\section{PENDAHULUAN}

Pendidikan bertujuan untuk meningkatkan kualitas hidup individu sebagai sumber daya manusia. Pendidikan dapat diselenggarakan dalam lingkup keluarga, masyarakat dan sekolah. Pendidikan yang merupakan sarana utama dalam pengembangan sumber daya manusia, hendaknya memperhatikan pemberdayaan komponen-komponen pendidikan dari ketiga lingkungan pendidikan tersebut. Satu komponen saja yang tidak mendukung tujuan pengembangan akan mengakibatkan kendala yang dicerminkan oleh hasil pendidikannya. Pendidikan keluarga merupakan bagian dari jalur pendidikan luar sekolah yang diselenggarakan dalam keluarga dan yang memberi keyakinan agama, nilai budaya, nilai moral dan keterampilan (UU RI No. 20 Tahun 2003). Dengan demikian keluarga mempunyai peranan penting dalam pendidikan, sehingga latar belakang keluarga harus diperhatikan agar keberhasilan pendidikan dicapai secara maksimal. 
Keberhasilan pendidikan merupakan tanggung jawab bersama antara keluarga (orang tua), anggota masyarakat dan pemerintah. Bahar (2007), menyatakan bahwa pada umumnya anak yang berasal dari keluarga menengah ke atas lebih banyak mendapatkan pengarahan dan bimbingan yang baik dari orang tua mereka. Anak anak yang berlatar belakang ekonomi rendah kurang dapat mendapat bimbingan dan pengarahan yang cukup dari orang tua mereka karena orang tua lebih memusatkan perhatiannya pada bagaimana untuk memenuhi kebutuhan sehari-hari. Hal ini sejalan dengan penelitian Restih (2016) menunjukkan bahwa terdapat pengaruh kondisi sosial ekonomi orang tua terhadap prestasi belajar siswa.

Selain status sosial ekonomi orang tua, faktor selanjutnya yang mempengaruhi prestasi belajar adalah adanya dorongan dari individu itu sendiri untuk berprestasi. Penelitian Saprudin (2014) juga menunjukan bahwa terdapat pengaruh langsung dan tidak langsung antara kondisi sosial ekonomi orang tua terhadap prestasi belajar ilmu pengetahuan sosial. Hal ini sesuai dengan pendapat Sanjaya (2008) menyatakan bahwa anak didik yang berprestasi rendah belum tentu disebabkan oleh kemampuan yang rendah pula, tetapi mungkin disebabkan oleh tidak adanya dorongan atau motivasi. Motivasi dapat diartikan sebagai daya penggerak dari dalam dan di dalam subjek untuk melakukan aktivitas-aktivitas tertentu dalam mencapai tujuan. Motivasi menurut Djamarah (2002) adalah suatu perubahan energi di dalam pribadi seseorang yang ditandai dengan timbulnya afektif (perasaan) dan reaksi untuk mencapai tujuan. Tella (2007), juga mengungkapkan bahwa prestasi timbul dari tinggi rendahnya motivasi yang dimilikinya, siswa yang mempunyai motivasi tinggi lebih baik prestasi akademiknya dari pada yang mempunyai motivasi rendah. Hasil penelitian yang dilakukan oleh Rondi (2015) menunjukkan bahwa secara simultan terdapat pengaruh yang signifikan antara kompetensi profesional guru dan fasilitas belajar terhadap motivasi dan prestasi belajar siswa.
Permasalahan - permasalahan yang digambarkan di atas mempengaruhi motivasi dan prestasi belajar siswa. Peneliti tertarik untuk mengetahui apakah ada faktor status sosial ekonomi orang tua siswa dan motivasi belajar pada prestasi belajar kimia siswa. Berkaitan dengan hal-hal yang dikemukakan di atas, peneliti melakukan penelitian dengan judul tesis Pengaruh Status Sosial Ekonomi Orang Tua dan Motivasi Belajar Siswa Terhadap Prestasi Belajar Kimia Siswa SMAN di Kabupaten Konawe.

\section{METODE}

Jenis penelitian yang digunakan adalah penelitian asosiatif karena penelitian ini bertujuan untuk mengetahui pengaruh status sosial ekonomi orang tua dan motivasi belajar terhadap prestasi belajar kimia pada siswa SMA Negeri di Kabupaten Konawe. Pendekatan yang digunakan adalah pendekatan kuantitatif dimana penelitian ini didasarkan pada angka-angka dan perhitungan secara matematis untuk menguji kebenaran suatu permasalahan. Lokasi penelitian ini adalah SMAN di kabupaten Konawe dimana pengumpulan data menggunakan angket dan nilai rapor belajar siswa. Pupulasi berjumlah 385 siswa. Penarikan sampel dilakukan dengan teknik acak proporsional (multisatge proporsional random sampling), dengan jumlah sampel sebanyak 193 orang. Data di analisis secara deskriptif dan inferensial. Analisis secara deskriptif dalam mendeskripsikan skor masing-masing variabel yang diteliti adalah menggunakan software microsoft exel. Analisis Inferensial dalam menguji hipotesis melalui uji Normalitas, Multikolinearitas, Heteroskedastisitas, Linearitas, menggunakan software SPSS 17.

\section{HASIL DAN PEMBAHASAN}

Ada bebrapa data yang menjadi hasil penelitian ini antara lain: 1. Hasil Analisis Deskriptif Besaran Variabel Status Sosial Ekonomi Orang Tua. 2. Hasil Analisis Deskriptif Variabel Motivasi Belajar Siswa. 3. Hasil Analisis Deskriptif Variabel Prestasi Belajar Kimia Siswa. 
1. Hasil Analisis Deskriptif Besaran Variabel Status Sosial Ekonomi Orang Tua
Hasil analisis deskriptif besaran variabel status sosial ekonomi orang tua disajikan dalam Tabel 1.

Tabel 1. Tabulasi Distribusi Frekuensi Status Sosial Ekonomi Orang Tua

\begin{tabular}{lccc}
\hline \multicolumn{1}{c}{ Indikator } & \multicolumn{3}{c}{ Jumlah siswa (\%) } \\
\cline { 2 - 4 } & Tinggi $\geq 80$ & Sedang $\geq 60$ & Rendah $<60$ \\
\hline 1. Tingkat pendidikan & 27 & 130 & 36 \\
\hline 2. Tingkat pendapatan & 3 & 156 & 34 \\
\hline 3. Kepemilikan fasilitas & 4 & 148 & 41 \\
\hline 4. Jenis rumah tinggal & 8 & 98 & 87 \\
\hline
\end{tabular}

Berdasarkan tabel di atas dapat disimpulkan bahwa sebagian besar responden memiliki status sosial ekonomi orang tua dengan kategori sedang artinya meskipun status sosial ekonomi orang tua dalam kategori sedang tetapi prestasi belajarnya tinggi. Maka disimpulkan bahwa kecenderungan status sosial ekonomi orang tua siswa SMAN di Kabupaten Konawe berada dalam kategori sedang.

\section{Hasil Analisis Deskriptif Variabel Motivasi Belajar Siswa}

Hasil analisis deskriptif variable motivasi belajar siswa telah disajikan dalam Tabel 2

Tabel 2. Tabulasi Distribusi Frekuensi Motivasi Belajar Siswa

\begin{tabular}{lcccc}
\hline \multicolumn{1}{c}{ Motivasi Belajar } & \multicolumn{3}{c}{ Jumlah siswa (\%) } \\
\cline { 2 - 4 } & Tinggi $\geq 80$ & Sedang $\geq 60$ & Rendah $<60$ \\
\hline 1. Siswa Pesisir & 0 & 86 & 4 \\
\hline 2. Siswa Daerah Aliran Sungai & 0 & 100 & 3 \\
\hline
\end{tabular}

Berdasarkan Tabel di atas dapat disimpulkan bahwa sebagian besar responden memiliki motivasi belajar dengan kategori sedang dengan persentase $\geq 60 \%$, artinya meskipun motivasi belajar siswa dalam kategori sedang tetapi prestasi belajarnya tinggi.

Tabel 3. Tabulasi Distribusi Frekuensi Prestasi Belajar Kimia Siswa

\begin{tabular}{lccc}
\hline \multicolumn{1}{c}{ Prestasi Belajar Kimia } & \multicolumn{3}{c}{ Jumlah siswa (\%) } \\
\cline { 2 - 4 } & Tinggi $\geq 80$ & Sedang $\geq 60$ & Rendah $<60$ \\
\hline 1. Siswa Pesisir & 23 & 67 & 0 \\
\hline 2. Siswa Daerah Aliran Sungai & 16 & 84 & 0 \\
\hline
\end{tabular}

Berdasarkan Tabel di atas disimpulkan bahwa sebagian besar responden memiliki prestasi belajar kimia dengan kategori sedang dengan persentase $\geq 60 \%$. artinya bahwa kecenderungan prestasi belajar kimia siswa SMAN di Kabupaten Konawe berada dalam kategori sedang. Disamping ke tiga hasil analisis diatas perlu meninjau hasil analisis inferensial.

\section{Hasil Analisis Deskriptif Variabel Prestasi Belajar Kimia Siswa}

Tabulasi distribusi deskriptif variabel pretasi belajar kimia siswa disajikan dalam Tabel 3. 
Tabel 4. Hasil Pengujian Normalitas Tiap Variabel

\begin{tabular}{|c|c|c|c|c|}
\hline \multirow{2}{*}{ Variabel } & \multicolumn{2}{|c|}{ Kolmogorov-Smirnov } & \multirow{2}{*}{ Kesimpulan } & \multirow{2}{*}{ Keterangan } \\
\hline & Statistik & Sig. & & \\
\hline Status sosial ekonomi orang tua & 1,397 & 0,469 & \multirow{3}{*}{$\mathrm{H}_{0}$ diterima } & \multirow{3}{*}{$\begin{array}{l}\text { Terdistribusi } \\
\text { normal }\end{array}$} \\
\hline Motivasi belajar & 1,543 & 0,547 & & \\
\hline Prestasi belajar kimia siswa & 1,659 & 0,784 & & \\
\hline
\end{tabular}

Data pada Tabel di atas menunjukkan bahwa data untuk tiap variabel memiliki nilai signifikansi $>0,05$, artinya data tiap variabel berasal dari populasi yang terdistribusi normal.

b. Uji Multikolinearitas

Tabel 5. Hasil Uji Multikoliniearitas

\begin{tabular}{lcc}
\hline \multirow{2}{*}{ Model } & \multicolumn{2}{c}{ Statistik Kolinearitas } \\
\cline { 2 - 3 } & Toleransi & VIF \\
\hline Status sosial ekonomi orang tua & 0,425 & 3,275 \\
\hline Motivasi belajar siswa & 0,425 & 3,275 \\
\hline
\end{tabular}

Tabel 5. menunjukkan bahwa tiap-tiap variabel independen mempunyai nilai Toleransi lebih besar dari 0,1 dan nilai VIF lebih kecil dari 10,00 yang menunjukkan bahwa tidak terjadi multikolinearitas terhadap data yang diuji.

\section{c. Uji Heterokedastisitas}

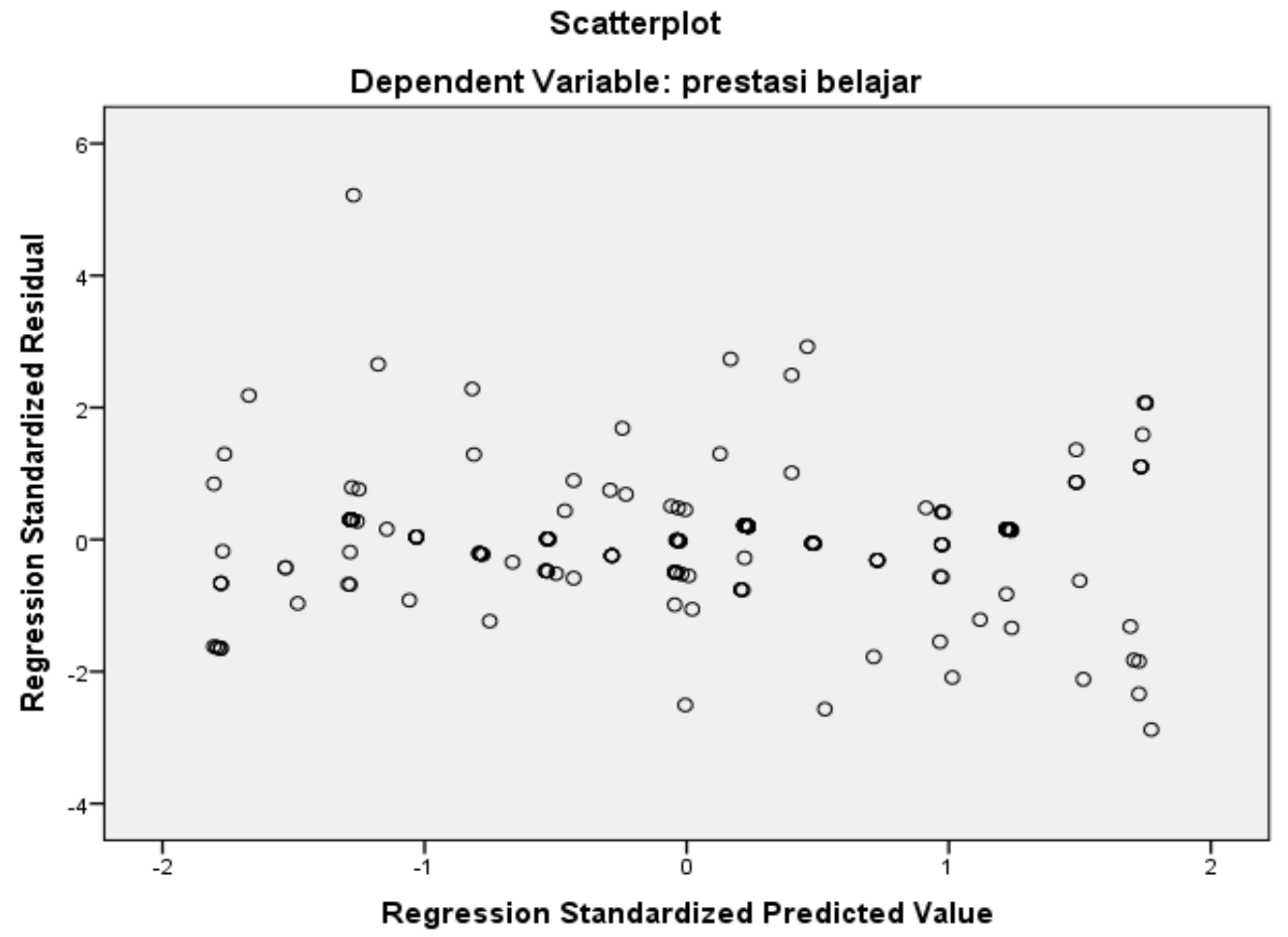

Gambar 1. Hasil Uji Heteroskedastisitas terhadap prestasi belajar kimia siswa

Berdasarkan Gambar tersebut terlihat titik-titik menyebar secara acak tidak membentuk sebuah pola tertentu yang jelas, serta tersebar baik di atas maupun dibawah angka 0 pada sumbu Y. hal ini menunjukkan bahwa tidak terjadi heteroskedastisitas pada model regresi. 


\section{d. Ujii Linearitas}

Tabel 6. Rangkuman Uji Linearitas Tiap Variabel

\begin{tabular}{|c|c|c|c|c|}
\hline \multirow[t]{2}{*}{ Kelompok data } & \multicolumn{2}{|c|}{$\begin{array}{l}\text { Deviasi dari } \\
\text { Linearitas }\end{array}$} & \multirow[t]{2}{*}{ Kesimpulan } & \multirow[t]{2}{*}{ Ket. } \\
\hline & $\mathrm{F}$ & $\mathrm{Sig}$ & & \\
\hline $\begin{array}{l}\text { Status sosial ekonomi orang tua*Prestasi } \\
\text { belajar }\end{array}$ & 1,631 & 0,210 & \multirow[t]{2}{*}{$\mathrm{H}_{0}$ ditolak } & \multirow[t]{2}{*}{ Linear } \\
\hline Motivasi belajar*Prestasi belajar kimia siswa & 1,329 & 0,311 & & \\
\hline
\end{tabular}

Berdasarkan Taabel diketahui bahwa antara kelompok data keseluruhannya mempunyai nilai signifikan $>0,05$ yang artinya terdapat hubungan linear yang signifikan antara tiap-tiap kelompok data.

\section{e. Uji Hipotesis}

Uji hipotesis pada penelitian ini adalah melihat efek beberapa variabel yang mempengaruhi prestasi belajar siswa yaitu:

Tabel 7. Rangkuman Hasil Analisis Regresi $X_{1}$ terhadap $Y$

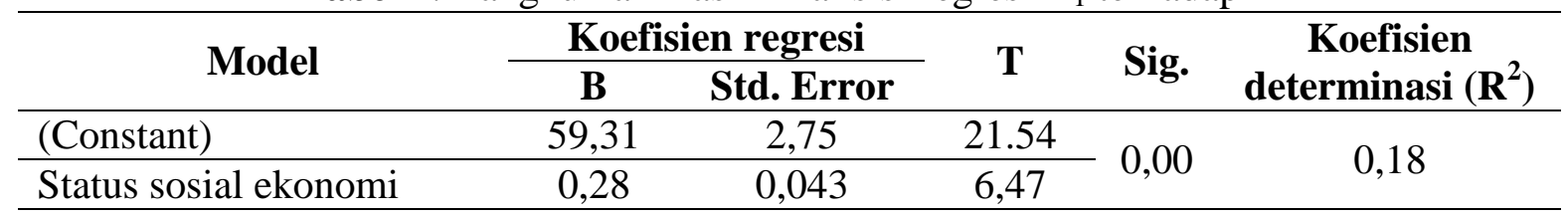

Intepretasi rangkuman hasil analisis regresi sederhana pada Tabel 5.7 di atas dapat dijelaskan sebagai berikut: Persamaan regresi sederhana ditentukan berdasarkan hasil koefisien regresi yang diperoleh. Hasil koefisien regresi membentuk persamaan

\section{1) Pengaruh Status Sosial Ekonomi Orang Tua Terhadap Prestasi Belajar Kimia Siswa}

Hipotesis pertama yang diajukan dalam penelitian ini menyatakan bahwa terdapat pengaruh positif dan signifikan status sosial ekonomi orang tua terhadap prestasi belajar kimia siswa.

Tabel 8. Rangkuman Hasil Analisis Regresi $X_{2}$ terhadap Y

\begin{tabular}{|c|c|c|c|c|c|}
\hline \multirow{2}{*}{ Model } & \multicolumn{2}{|c|}{ Koefisien regresi } & \multirow[t]{2}{*}{$\mathbf{T}$} & \multirow[t]{2}{*}{ Sig. } & \multirow[t]{2}{*}{$\begin{array}{c}\text { Koefisien determinasi } \\
\left(\mathbf{R}^{2}\right)\end{array}$} \\
\hline & B & $\begin{array}{l}\text { Std. } \\
\text { Error }\end{array}$ & & & \\
\hline (Constant) & 47,76 & 3,32 & 14,36 & \multirow{2}{*}{0,00} & \multirow{2}{*}{0,29} \\
\hline motivasi belajar & 0,443 & 0,05 & 8,83 & & \\
\hline
\end{tabular}

Intepretasi rangkuman hasil analisis regresi sederhana pada Tabel di atas dapat dijelaskan sebagai berikut: persamaan regresi sederhana ditentukan berdasarkan hasil koefisien regresi yang diperoleh. Hasil koefisien regresi membentuk persamaan regresi pengaruh motivasi belajar $\left(\mathrm{X}_{2}\right)$ terhadap prestasi belajar kimia $(\mathrm{Y})$ yaitu $\mathrm{Y}=$ regresi pengaruh status sosial ekonomi orang tua $\left(\mathrm{X}_{1}\right)$ terhadap prestasi belajar kimia siswa (Y) yaitu $\mathrm{Y}=59,31+0,28 \mathrm{X}_{1}$.

\section{2) Pengaruh Motivasi Belajar Terhadap Prestasi Belajar Kimia}


motivasi belajar mampu menjelaskan prestasi belajar kimia sebesar $29 \%$. Sedangkan sisanya sebesar $71 \%$ dipengaruhi atau dijelaskan oleh variabel lain yang tidak dimasukkan dalam penelitian ini. Pada uji hipotesis secara parsial dilakukan untuk melihat pengaruh motivasi belajar terhadap prestasi belajar kimia. Pada uji pengaruh motivasi belajar terhadap prestasi belajar kimia diperoleh nilai sig. $=0,00<\alpha=$ 0,05 yang artinya $\mathrm{H}_{0}$ ditolak. Dengan ditolaknya $\mathrm{H}_{0}$ maka dapat disimpulkan bahwa motivasi belajar berpengaruh positif dan signifikan terhadap prestasi belajar kimia.
Temuan ini memberi makna bahwa semakin besar motivasi belajar yang dimilki oleh peserta didik maka akan meningkatkan prestasi belajarnya.

3) Uji Perbedaan Motivasi Belajar Antara Siswa Pesisir dengan Siswa di Daerah Aliran Sungai

Hipotesis ketiga yang diajukan dalam penelitian ini menyatakan bahwa terdapat perbedaan motivasi belajar antara siswa yang berdomisili di pesisir dengan siswa yang berdomisili di DAS.

Tabel 9. Hasil Analisis Uji-t Perbedaan Motivasi Belajar Siswa

\begin{tabular}{ccccc}
\hline \multirow{2}{*}{ Variabel } & \multicolumn{2}{c}{ Levene's Test } & \multicolumn{2}{c}{ t-test } \\
\cline { 2 - 5 } & F & Sig & T & Sig. \\
\hline Motivasi belajar siswa & 0,935 & 0,335 & 4,335 & 0,002 \\
\hline
\end{tabular}

Intepretasi rangkuman hasil analisis uji-t pada tabel di atas dapat dijelaskan sebagai berikut: Hasil uji Levene's Test diperoleh nilai sig. = $0,335>\alpha=0,005$ yang menunjukan bahwa kelompok data motivasi belajar yang diuji terdapat kesamaan varians antar kelompok atau yang berarti homogen. Hasil Uji-t diperoleh nilai sig $=0,002<\alpha=0,005$ yang menunjukan $\mathrm{H}_{0}$ ditolak dan $\mathrm{H}_{1}$ diterima. Sehingga dengan ditolaknya $\mathrm{H}_{0}$ maka dapat disimpulkan bahwa terdapat perbedaan motivasi belajar antara terdapat perbedaan

Tabel 10. Hasil Analisis Uji-t Perbedaan Prestasi Belajar Kimia Siswa

\begin{tabular}{ccccc}
\hline \multirow{2}{*}{ Variabel } & \multicolumn{2}{c}{ Levene's Test } & \multicolumn{2}{c}{ t-test } \\
\cline { 2 - 5 } & $\mathbf{F}$ & Sig & T & Sig. \\
\hline Prestasi belajar kimia & 0,138 & 0,711 & 3,033 & 0,003 \\
\hline
\end{tabular}

Intepretasi rangkuman hasil analisis uji-t pada tabel di atas dapat dijelaskan sebagai berikut: Hasil uji Levene's Test diperoleh nilai sig. $=$ $0,711>\alpha=0,05$ yang menunjukan bahwa kelompok data prestasi belajar yang diuji terdapat kesamaan varians antar kelompok atau yang berarti homogen. Hasil Uji-t diperoleh nilai sig $=0,003<\alpha=0,05$ yang menunjukan $\mathrm{H}_{0}$ ditolak dan $\mathrm{H}_{1}$ diterima. Sehingga dengan ditolaknya $\mathrm{H}_{0}$ maka dapat disimpulkan bahwa terdapat perbedaan prestasi belajar antara terdapat perbedaan prestasi belajar antara siswa yang berdomisili motivasi belajar antara siswa yang berdomisili di pesisir dengan siswa yang berdomisili di DAS.

4) Uji Perbedaan Prestasi Belajar Antara Siswa Pesisir dengan Siswa di Daerah Aliran Sungai

Hipotesis keempat yang diajukan dalam penelitian ini menyatakan bahwa terdapat perbedaan prestasi belajar antara siswa yang berdomisili di pesisir dengan siswa yang berdomisili di DAS. 
dalam belajar, sehingga peserta didik yang memiliki motivasi belajar yang tinggi akan belajar dengan senang dan sukarela. Sebaliknya peserta didik yang tingkat motivasinya rendah akan mempunyai minat dan semangat yang rendah pula dalam belajar dan malas untuk mengikuti proses pembelajaran.

\section{SIMPULAN}

Berdasarkan data hasil penelitian ini dapat disimpulkan bahwa status sosial ekonomi orang tua berpengaruh terhadap prestasi belajar kimia siswa SMA Negeri di Kabupaten Konawe yang ditunjukkan dengan hasil analisis regresi sederhana dengan kontribusi sebesar 18\%. Motivasi belajar siswa berpengaruh terhadap prestasi belajar kimia siswa SMA Negeri di Kabupaten Konawe yang ditunjukkan dengan hasil analisis regresi sederhana dengan kontribusi sebesar $29 \%$. Terdapat perbedaan motivasi belajar antara siswa pesisir dengan siswa di Daerah Aliran Sungai di Kabupaten Konawe.

\section{DAFTAR PUSTAKA}

Bahar. 2007. Sosiologi Pendidikan. Bandung: Bumi Aksara.

Djamarah, B. S. 2000. Guru dan Anak Didik dalam Interaksi Edukatif. Jakarta: PT Rineka Cipta.

Prabawa, K, A. 2014. Pengaruh Sosial Ekonomi dan Perhatian orang tua Terhadap Prestasi Belajar Ekonomi siswa kelas IX. Jurnal Ekonomi. 4 (1), 144-151.

Purwati, A. 2011. Pengaruh Status Sosial Ekonomi Orang Tua, Persepsi Atas Lingkungan, Dan Prestasi Belajar Ekonomi Terhadap Perilaku Konsumsi. Jurnal Ekonomi Bisnis. 16 (1), 124-126.

Restih. 2016. Pengaruh Status Sosial Ekonomi Orang Tua Terhadap Prestasi Belajar Geografi Siswa Kelas X SMAN 20 Konsel. (Skripsi) Program Studi Ilmu Pengetahuan Sosial. Fakultas Keguruan dan Ilmu Pendidikan. Universitas Halu Oleo.

Rondi, A. 2015. Pengaruh Kompetensi Guru Dan Fasilitas Belajar Terhadap Motivasi Dan Prestasi Belajar Siswa Pada Mata
Pelajaran Ekonomi. Tesis. Yogyakarta: Universitas Negeri Yogyakarta.

Sanjaya, M.Y. 2018. Pengaruh status sosial ekonomi, motivasi berprestasi, dan efikasi diri terhadap hasil belajar ekonomi siswa kelas XI IIS SMA Islam GunungJati Ngunut Tulungagung. Tesis Pascasarjana Pendidikan Ekonomi Universitas Negeri Malang.

Saprudin, Wahjoedi, Utami Widianti. 2014. Kondisi Sosial Ekonomi Orang Tua dan Motivasi Belajar Terhadap Prestasi belajar Ilmu Pengetahuan Sosial. Jurnal Pendidikan IPS. Program Pascasarjana Universitas Negeri Malang.

Tella, M. Y. 2007. "Pengaruh status sosial ekonomi, motivasi berprestasi, dan efikasi diri terhadap hasil belajar ekonomi siswa kelas XI IIS SMA Islam GunungJati Ngunut Tulungagung”. Tesis Pascasarjana Pendidikan Ekonomi Universitas Negeri Malang. 